\title{
Chapter 14 \\ Pension Systems Compared: A Polarised Perspective, a Diverse Reality
}

\author{
Patricia Scarponetti, Leandro Sepúlveda, and Antonio Martín-Artiles
}

\begin{abstract}
Globalisation and international competition have a spillover effect on the reforms of pension systems that imposes a similar pattern of dismantling, hardening access to pensions, reducing expenditure and retrenchment in said reforms. The comparative analysis of four countries with different pension systems: two liberal (United Kingdom and Chile) and another two with contributory-proportional systems (Spain and Argentina) serves to determine the details of the reform processes, which discursively seem to have a shared pattern recommended by the international financial and economic institutions.

But the reality of the four case studies shows considerable differences in the implementation of the pension reform policies. The reforms depend on the societal context, institutions, history, the role of unions, the government in power, demographic factors and economic perspectives, among other matters. Many countries need to sustain pension systems because they are associated with many pensioners' political vote. Therefore, the spillover effect of globalisation and the convergence in certain uniform patterns of reforms is far from reality in the four countries, and as such, the measures adopted are specific for each country.
\end{abstract}

Keywords Pensions - Occupational pensions · Reform policies · Globalisation · Social dialogue $\cdot$ Neoliberalism $\cdot$ Corporatism

\footnotetext{
P. Scarponetti $(\bowtie)$

Centro de Estudios Avanzados, Universidad Nacional de Córdoba, Córdoba, Argentina

L. Sepúlveda

Centre for Enterprise and Economic Development Research, Middlesex University Business

School, London, UK

e-mail: L.Sepulveda@mdx.ac.uk
}

\author{
A. Martín-Artiles \\ Centro de Estudios Sociológicos sobre la Vida Cotidiana y el Trabajo - Instituto de Estudios \\ del Trabajo, Universidad Autónoma de Barcelona, Barcelona, Spain \\ e-mail: Antonio.Martin@uab.cat
}




\subsection{Introduction}

The aim of this chapter is to analyse the changes (1) in the public contributively pension systems protected by the State (pay-as-you-go) and (2) the private capitalisation pensions, managed by insurance companies or banks. The latter are divided into two: (a) on the one hand, occupational capitalisation pensions, which involve financing from a company and voluntary contributions from the employees; (b) on the other hand, private capitalisation pensions taken out individually by a person with a bank or an insurance company (Del Pino and Rubio Lara 2016). Today, resuming the debate about pensions, from a comparative inequality studies perspective, entails describing their oscillating nature in some countries in Latin America, as well as the redesigning that has taken place in European countries since the Great Recession (2008-2015).

For the case of some countries from the southern cone-Argentina, Uruguay and Brazil, with the exception of Chile_-said movement can be contextualised via complex processes of social change, which took place during the last decades of the twentieth century and the first decades of the present century. While, on the one hand, the re-democratisation processes in the region operated in societies with an optimism based on recovering the protective role of the State, in parallel, the public policies implemented did not manage to overcome the economic downturns, giving rise in the 1990s to the beginning of a cycle of adjusting fiscal expenditure in the conditioning context of external debts. Both processes happened during the global reorganisation of austerity capitalism that reconfigured the economy, and in particular the labour markets.

Said political and economic reconfigurations became a focal point of discussion because they blocked the stability of traditional social protection and therefore the welfare of the populations, in this case that of elderly adults, placing the democratic design at a point of tension between the State and the market. It is no coincidence that every once in a while, citizens' claims against adjustment or against neoliberal policies are repeated. Today we are witnessing mass citizens' demands in Chile ${ }^{1}$ and Colombia, as well as on the other side of the Atlantic in France, and not too long ago, in Spain and the United Kingdom. In all of these, people have been protesting about pensions in very different contexts. The discourse calling for the negotiation of new social pacts after the changes of a globalised economy, once again polarises societies about how to provide social welfare in democratic designs.

In Latin America, social welfare systems have traditionally been divided into contributory and non-contributory systems. ${ }^{2}$ While the contributory Social Security is generated from payments by the insured and by employers with state guarantees based on the diverse conditions and positions in the labour market, on the contrary,

\footnotetext{
${ }^{1}$ Beyond the range of claims in the Chilean citizens' movement that began in October 2019, the NoMásAFP movement is notable in reference to the pension capitalisation system managed by the pension fund managing companies.

${ }^{2}$ While some literature in Latin America uses the term "pillars", a word taken from the first report from the World Bank and the OCDE, its use is less frequent.
} 
the non-contributory Social Security is rendered viable through public policies aimed at those who do not meet all the terms and is executed through a financing of revenues and general taxes or with surpluses from the contributory systems. Noncontributory pensions in Latin America were limited when these systems initially came into effect; however, they experienced considerable growth in recent years in order to ease the living conditions of the most vulnerable population. Their growing evolution has played a very important role in the debate, by accompanying the trends in the reforms of the state welfare systems towards individual capitalisation systems, in which the employer's contribution disappears and the State's role becomes subsidiary.

As stated by Bertranou (2006 and Bertranou et al. 2009), the reforms of the 1990s adjusted financial and economic goals to move towards capitalisation while in the first decade of the present century the poverty-relief goals were readjusted, and as such the coverage was extended to those sectors lacking contributory conditions. Based on these considerations, the reflection made by Mesa-Lago (2004: 99) is relevant. He highlights the enormous diversity of pension systems in countries of Latin America, summarised in three different models: substitutive, parallel and mixed. However, beyond the perspective of this double division of welfare systems into contributory and non-contributory ones, state (public) and capitalisation (private or mixed), there are permanent reforms to the parameters which reconfigure the ages to access the benefit, the increase in the years of contribution, redefinitions of the formulae to calculate the amount to be received; aspects that contribute towards the increase in gender or age inequality.

Beyond the pioneering example of Chile which reformed its state welfare system to a capitalisation regime in 1980, the reforms that followed this model proved to be loss-making either because they did not comply with the objectives set out, or because they could not be sustained in adverse economic contexts. As a result of the critical contexts in both continents since 2008, new reforms were subsequently considered. In Latin America they were known as re-reforms; such as in Argentina and Chile, among other countries (Becker and Mesa-Lago 2013).

Furthermore, a specialised literature review highlights the existence of a series of points in common in the reforms implemented in the European Union (European Commission 2012), through the Open Method of Co-ordination (OMC). The successive reforms of the welfare state have demonstrated a trend towards the reduction of expenditure on pensions, strongly conditioned by debt and public deficit in countries such as Spain, Italy, Greece, Portugal and Ireland, as we will see below. This context favours the emergence of two theories on the reformist trends in pensions. On the one hand, the idea of the Active Welfare State, a liberal-social proposal that defends the maintenance of the welfare state, introducing the principle of activation. Both the OCDE and the European Union have supported and promoted its objectives, mentioned again through the European 2020 Strategy by the European Commission (Rubio Lara 2016). On the other hand, the conservative proposal of the Investor-State considers that the sustainability of the welfare state depends on the medium-term growth rates, and in turn, this depends on investment in R\&D (research and development), human capital and the spread of new technologies (Palier 2010). 
Therefore, the principle guiding this policy is the "return on investment". However, both theories often have points in common, as we will see below.

We face similar problems in the countries from both continents, but to different extents. These are precarious labour markets, the transcontinental migratory explosion, ageing of the population, public debt and the financial downturn. While in the European Union the balance between the active and inactive population in forecasts for 2050 is concerning, the same can be said for some Latin American countries. Flexible and precarious labour markets, with low salaries and high vulnerability of social rights, fuelled by a migratory work force from other countries in the region, have turned the debate about pensions into a tight knot that jeopardises the traditional views of social protection.

Considering these conditions, the forecast of the expenditure on pensions for the countries from both continents is concerning, and even more so when in each situation in which the fiscal deficit intensifies, the advice to introduce structural reforms or changes in restrictive parameters is repeated, as well as the insistence to turn towards capitalisation systems. In this way, the definitions of who retires and in what conditions (age, pension sum) and with what financing-whether state or capitalisation-gives rise to a debate that is under no circumstances resolved.

With a view to performing a comparative treatment to give an account of the effects of the reforms implemented and their consequent trends, we have selected case studies of two European countries (Spain and the United Kingdom) and two Latin American countries (Chile and Argentina). The choice of the two former countries serves to show the trends towards private occupational pensions-although with very different degrees of implementation-while, in the latter two, we situate the trends of re-reforms in two different cases: a capitalisation system and a state system.

Our analysis is based on the comparison of different welfare models and their reform policies. In the countries studied the dominant discourse is about the need to reform pensions to facilitate sustainability in the context of globalisation (spillover effect). One of the options lies in the implementation of negotiated occupational welfare (Trampusch 2007), but its implementation depends on the political context, its institutions of collective negotiation and the role of unions and employers. In other words, reference to the context reminds us of the importance of "societal factors", history, local institutions and the role of social actors, such as unions, employers and the government, among others (Boyer 2005). Thus, the hypothesis we formulate is that the reform policies of pensions do not follow a standard pattern imposed by the demands of globalisation, but the responses differ according to the institutional context.

In the context of these considerations, this chapter is structured in five sections after this introduction. In the first section, we will review the social protection system in the context of the global economy and the subsequent theoretical discussion of two paradigms: Neoliberalism and the Active Welfare State. In the second section, we will conduct a brief statistical analysis to identify the general models into which pension systems fall in Argentina, Chile, Spain and the United Kingdom, providing us with a comparative framework with other countries. In the third 
section the possible elements of convergence of the reforms brought on by globalisation in pension policies (spillover effect) are discussed, as well as the general responses. In the fourth section we will analyse the cases of the four countries in depth, which will show us how there have been different responses to similar problems, although there have also been common elements in the responses. Lastly, in the fifth section, we will draw some conclusions.

\subsection{Social Protection in the Context of Global Economies}

Vast literature has been written about the transformation of the welfare state, which Adelantado and Calderón $(2005,2006)$ summarise in three explanations: (1) the transformations are due to external globalisation pressures (spillover effect) that have forced governments to reduce social expenditure, fiscal pressure, to make the labour market more flexible, to decentralise collective negotiation to business level, among other factors due to international competition; (2) another argument is that the transformations of the welfare state are due to internal factors resulting from pressure from social actors, such as employers and unions, to the ageing of the population and the subsequent increase in expenditure on pensions and health, and the move towards a services economy with jobs with lower average salaries that in industry and, consequently, fewer revenues from Social Security payments; (3) the third explanation consists of the combination of both factors in which exogenous and endogenous factors influence each other, giving rise to multiple responses, depending on the local institutional context. In this context of reforms in recent decades, new concepts have appeared, such as the Active Welfare State and the Investor State (Vielle et al. 2005; Palier 2010).

\subsubsection{The Neoliberalism Crisis: A Change of Paradigm in Europe?}

Although the theory of the Investor State has a conservative connotation and the Active Welfare State is of a social-liberal nature (Boyer 2005), we could agree that they today form part of a new paradigm that appears in the literature of advanced European economies from 1995. The term Active Welfare State seems more appropriate to use because it goes beyond the economic perspective, it is more sociological and includes an institutional dimension, social and labour rights, and social actors (unions, employers, third sector, etc.). Moreover, it is essentially a new and different paradigm that is alternative to neoliberalism (Arnsperger 2005). Therefore, we are facing a potential crisis of the neoliberal paradigm which has dominated the political scene from 1980 to the present day in the European context. 
In the last decade a crisis of the liberal paradigm and its political formulae to deal with unemployment, pensions and social protection seems to have begun. Indicators of this are, among other phenomena, the rise in protectionism, nationalism and regionalism, Brexit, the mass demonstrations in Chile and France and protests of pensioners in Spain in response to the uncertainty and rise in inequalities (Campos Lima and Martín Artiles 2014, 2018). Therefore, it should come as no surprise that the Active Welfare State is a response to the neoliberalism crisis as a new emerging paradigm (see Table 14.1).

As regards intervention of the State, neoliberal approaches have defended the idea of the Minimum State. On the contrary, the Active Welfare State paradigm argues the need to sustain the state's role in the economy and welfare, but linked to the return on investment in initial and continuous training, as well as support for production (Vielle et al. 2005).

As regards the prediction of retirement pensions, the neoliberals have proposed the expansion of individual private pension plans. On the contrary, the Active Welfare State proposes a strategy of a Multi-pillar Welfare State with different

Table 14.1 Comparison neoliberalism \& social active state

\begin{tabular}{|c|c|c|}
\hline & $\begin{array}{l}\text { Neoliberalism } \\
1979-1995\end{array}$ & Social active state $1995-2020$ \\
\hline $\begin{array}{l}\text { 1. State } \\
\text { intervention in } \\
\text { economy }\end{array}$ & Minimum State & $\begin{array}{l}\text { Public investment oriented to return, support to } \\
\text { production and social redistribution }\end{array}$ \\
\hline 2. Welfare State & $\begin{array}{l}\text { Dismantlement } \\
\text { Workfare not Welfare }\end{array}$ & $\begin{array}{l}\text { Financial sustainability of Welfare } \\
\text { Agenging societies and pressions of voters on } \\
\text { labour parties and trade unions }\end{array}$ \\
\hline $\begin{array}{l}\text { 3. Retirement } \\
\text { Pensions }\end{array}$ & Private pensions plans & $\begin{array}{l}\text { Multipillar Welfare State, diversifications } \\
\text { sources of financialization } \\
\text { - Contributively and proportional pensions } \\
\text { - Assistance pensions } \\
\text { - Occupational pensions } \\
\text { - Private pensions plans } \\
\text { - Implementation third sector }\end{array}$ \\
\hline $\begin{array}{l}\text { 4. Employment } \\
\text { Strategy }\end{array}$ & $\begin{array}{l}\text { Oriented to market } \\
\text { Individual merit } \\
\text { Activation } \\
\text { Flexibilization of labour } \\
\text { market }\end{array}$ & $\begin{array}{l}\text { Individual merit and social cohesion } \\
\text { Future return of investment policies } \\
\text { Activation, employability; continuous training }\end{array}$ \\
\hline $\begin{array}{l}\text { 5. Collective } \\
\text { Bargaining Level }\end{array}$ & $\begin{array}{l}\text { Limited at company level } \\
\text { Decentralisation } \\
\text { collective bargaining }\end{array}$ & $\begin{array}{l}\text { Social Pacts: articulation between levels, Trend } \\
\text { to desentralisation collective bargaining } \\
\text { Occupational Pensions: Negotiated Welfare } \\
\text { corporatist }\end{array}$ \\
\hline 6. Assistance & $\begin{array}{l}\text { Guarantee Minim } \\
\text { Income } \\
\text { Workfare }\end{array}$ & $\begin{array}{l}\text { Assistance policy against poverty but linked } \\
\text { with conditionality of incomes: training, } \\
\text { searching for activation, employability }\end{array}$ \\
\hline 7. Social Policy & $\begin{array}{l}\text { Assistance, first social } \\
\text { policy it is employment }\end{array}$ & $\begin{array}{l}\text { Articulation between active employment } \\
\text { policies and social policy: conditionality of } \\
\text { social protection }\end{array}$ \\
\hline
\end{tabular}

Source: Own elaboration 
sources of finance to guarantee its sustainability (Comisión Europea 2003), such as contributory-proportional public pensions, welfare pensions to relieve the poverty risk, negotiated occupational pensions in companies, individual pension plans with tax allowances and the intervention of the third sector in the area due to the decentralisation of the welfare policies (European Commission 2012).

As regards the implementation strategy, liberal thinking has been characterised by Margaret Thatcher's famous thought in the 1980s, that we could summarise as: more market less State, more entrepreneurship less unions (see Harrison 2011: 331-332) This strategy is complemented by the idea that social merit is an essential condition for upward social mobility. The Active Welfare State also proposes individual merit, but associated with the return on investment in training, activation, employability and continuous life training, without neglecting the need for social cohesion. Social dialogue between unions, employers and the State is important. Therefore, collective negotiation and social pact are important elements to construct negotiated occupational welfare (Trampusch 2007).

Lastly, regarding welfarism, the newest feature of the neoliberal proposal against extreme poverty could be related to the guaranteed minimum income, but with the hidden intention of paying the Welfare State. On the contrary, the paradigm of the Active Welfare State proposes a welfare policy linked to the conditionality of the benefit, which consists of more continuous training and active job-seeking (European Commission 2012). The proposal is to link the active job-seeking policies with the passive benefit policies; in other words, to link pre-distributive and post-distributive policies (Zalakain and Barragué 2017).

In short, we can deduce that the link between passive and active policies is a challenge to sustain the welfare state. Therefore, it is understood that from the Active Welfare State theory we are facing a double challenge to implement the predistributive policy in the collective negotiation to guarantee income from salaries and their respective contributions via social contributions, while also implementing a post-distributive policy that sustains the pension system. Let us remember that some analysts understand that this policy should be accompanied by changes in financing (Clasen and Clegg 2012) through the diversification of the sources of funding through a multi-pillar system ${ }^{3}$; this political strategy-promoted by the European Union-seeks to diversify the funding so as not to depend on contributory pensions, the demographic effects of the ageing of the population, and the changes in the labour market. These changes explain the move from Welfare to Workfare stemming from the concept of the Active Welfare State (Boyer 2005). In other

\footnotetext{
${ }^{3}$ In accordance with Liedo (2005), the social security systems described as "multi-pillar" have been adopted from the taxonomy proposed by the WB and the OCDE based on three pillars corresponding to: "Pillar 1: a redistributive and anti-poverty system financed with taxes, relatively small, with defined benefit and publicly managed; Pillar 2: a defined contribution system of compulsory capitalisation and privately managed through a personal or occupational plan; Pillar 3: a voluntary defined contribution system, of capitalisation and privately managed. The World Bank doctrine proposes the separation of the redistribution functions from the saving functions in social security systems".
} 
words, a reduction in the redistributive intervention of the State with protective criteria to correct the former post-distributive inequalities to another pre-distributive policy, associated with activating unemployed people towards employability, active job-seeking and the extension of the retirement age because life expectancy is increasing. In other words, as described in the second chapter of this book, there is a tendency to emphasise the importance of pre-distributive policies to the detriment of post-distributive policies (Zalakain and Barragué 2017).

Nevertheless, some analysts express their doubts about the supposed new paradigm of the Active Welfare State and the Investor State. The paradigm of social investment has been presented as a new model of the welfare state that differs both from the Keynesian welfare state and the neoliberal model, with a wide consensus in antagonistic political positions such as social democracy and conservative driving forces. However, under said paradigm, such different models of social investment are considered that Rubio Lara (2016) expressed his doubts as to whether this really establishes a break with the neoliberal trend.

\subsubsection{Re-reforms in Latin America}

A considerable difference is the weak institutionalisation of the pension and social protection systems (Ubasart and Minteguiaga 2017) in Latin America. Likewise, the neoliberal paradigm has dominated the political discourse. The impacts of the neoliberal economic reconfigurations in the Latin American countries brought about reforms in the social security systems in the region, backed by international finance organisations. The World Bank (1994) instigated the reforms of the pension systems in various countries in the region; with its famous report Envejecimiento sin Crisis (1994) [Ageing without Crisis], it laid down the foundations of the structural reforms towards a multi-pillar system that recommended both the strengthening of the capitalisation and non-contributory pillars; the main goal was to encourage the replacement of the public "defined benefit" based on "distribution", with individual capitalisation systems of "defined contribution". These reforms reduced the state function and introduced new economic agents such as private pension funds, essential actors in a capital market (Tangarife et al. 2015). ${ }^{4}$

In 2004, Mesa-Lago produced an analysis for CEPAL with the aim of comprehensively comparing the impact of pension reforms in the context of the traditional principles of the Social Security. With a view to observing the divergence of stances with the principles established by the International Labour Organization and the International Association of Social Security, the author presents an analysis of how the principles protected by the treaties promoted by these organisations adapted to

\footnotetext{
${ }^{4}$ A decade later, the World Bank would publish another document: "Keeping the Promise of Old Age Income Security in Latin America" (2004), described by some analysts "as a self-criticism" of its first report.
} 
the economic criteria of the reforms driven by the World Bank and the International Monetary Fund.

Welfare pensions have also been part of social policy in Latin America, and demonstration of poverty is demanded. The paradigmatic example is observed in the reform of the Chilean social security system that took place in 2008 and once again placed the tension between focalisation and universalisation at the centre of the debate. The political discourse surrounding welfarism has also been linked to the demands for activation, employability and conditionality of the benefits, although in actual fact this policy is still underdeveloped as a result of the high costs of managing unemployment, as shown in Chap. 13 of this book.

In the academic debate in Latin America, it has been insistently proposed that the social security system reforms replaced the distribution regime with the capitalisation regime, in such a way that the political intervention of the state now has a subsidiary role. In this regard, it is important to remember that maintained by Del Valle (2010) regarding how the commercialisation levels operating in society are defined. The author's comment must be related to the necessary intervention of the state and to the informality of the labour markets in the region. In short, the Latin American social model can be defined as Structural Heterogeneity resulting from the combination of formal economy, informal economy, double currency (dollar + local currency), family economy and weak institutionalisation of social protection (see Chap. 2). ${ }^{5}$

\subsection{Classification of Pension Regimes}

This classification analysis seeks to discuss each of the four countries studied in the context of welfare models. The construction model of this classification of pension regimes was created using five variables (Table 14.2).

- The first variable is the GDP per capita. This variable conditions the possibilities of social expenditure, expenditure on pensions, in particular, but it also conditions

\footnotetext{
${ }^{5}$ Del Valle (2010: 66-67). Del Valle (2010) criticises the argument "we could put forward the theory that, in all societies with a market economy, the forms of state intervention in social relations stem from the systemic relation that exists between the State and the economy". Following that put forward by Offe \& Ronger, he specifies that "distribution refers to the intervention via which the State assigns resources which it already monitors or obtains through coercive exercise (laws, decrees, etc.) in order to guarantee processes of accumulation of capital. (...) the existence of underground activities can be interpreted as the result of the forms of state intervention, it can be stated that these cannot be interpreted as reflections of current transformations in the supposed path towards modernisation but as a structural part of the functioning of Latin American systems. (...) and a political dimension, given by the way the State intervenes in the stratification processes, and this is due to its role in the assigning of resources, in other words, as an agent that takes resources from some people and gives them to others. In this regard, the State defines the commercialisation levels operating in society, since the practice of assigning resources reproduces, amplifies and reduces stratification processes".
} 
Table 14.2 Retirement pensions regime indicators

\begin{tabular}{|c|c|c|c|c|c|}
\hline Country & $\begin{array}{l}\text { Informal } \\
\text { employment }\end{array}$ & $\begin{array}{l}\text { GDP per } \\
\text { capita }\end{array}$ & $\begin{array}{l}\text { Social } \\
\text { expenses } \\
(\% \text { GDP) }\end{array}$ & $\begin{array}{l}\text { Public pensions } \\
\text { expenses (\% GDP) }\end{array}$ & $\begin{array}{l}\text { Private pensions } \\
\text { plans (\% GDP) }\end{array}$ \\
\hline Argentina & 47.1 & 21,064 & 14.3 & 7.8 & 10.2 \\
\hline Austria & 10.0 & 53,895 & 26.6 & 13.9 & 5.5 \\
\hline Belgium & 13.5 & 49,526 & 28.9 & 11.8 & 7.3 \\
\hline Brazil & 46.8 & 15,651 & 15.1 & 9.1 & 12.6 \\
\hline Bulgaria & 15.9 & 20,948 & 16.0 & 0.0 & 12.5 \\
\hline Chile & 22.2 & 24,181 & 16.1 & 5.1 & 70.2 \\
\hline $\begin{array}{l}\text { Czech } \\
\text { Republic }\end{array}$ & 9.2 & 38,037 & 18.7 & 9.0 & 8.9 \\
\hline Denmark & 11.2 & 54,337 & 28.0 & 10.3 & 45.4 \\
\hline Finland & 6.3 & 46,344 & 28.7 & 12.9 & 47.7 \\
\hline France & 9.8 & 44,125 & 31.2 & 14.9 & 0.7 \\
\hline Germany & 10.2 & 52,574 & 25.1 & 10.0 & 6.7 \\
\hline Greece & 32.8 & 28,580 & 23.5 & 16.2 & 0.7 \\
\hline Hungary & 12.2 & 28,799 & 19.4 & 11.5 & 3.9 \\
\hline Ireland & 13.5 & 76,889 & 14.4 & 7.4 & 31.6 \\
\hline Italy & 19.0 & 40,981 & 27.9 & 15.7 & 7.6 \\
\hline Mexico & 57.0 & 19,655 & 7.5 & 1.8 & 14.1 \\
\hline Netherlands & 9.4 & 54,423 & 16.7 & 6.9 & 171.0 \\
\hline Norway & 7.3 & 62,182 & 25.0 & 9.9 & 9.8 \\
\hline Poland & 38.0 & 29,583 & 21.1 & 11.3 & 7.5 \\
\hline Portugal & 12.1 & 32,554 & 22.6 & 13.8 & 9.7 \\
\hline Romania & 28.9 & 26,590 & 14.9 & 0.0 & 5.2 \\
\hline Slovakia & 16.7 & 32,376 & 17.0 & 8.1 & 11.7 \\
\hline Slovenia & 5.0 & 36,163 & 21.2 & 11.8 & 5.6 \\
\hline Spain & 27.3 & 39,087 & 23.7 & 11.4 & 8.8 \\
\hline Sweden & 8.2 & 51,405 & 26.1 & 8.9 & 4.1 \\
\hline $\begin{array}{l}\text { United } \\
\text { Kingdom }\end{array}$ & 13.3 & 44,909 & 20.6 & 7.7 & 104.5 \\
\hline Uruguay & 44.3 & 11,739 & 16.0 & 0.0 & 27.1 \\
\hline USA & 36.0 & 59,774 & 18.7 & 4.9 & 76.3 \\
\hline
\end{tabular}

Sources: ILO (2019) and OECD (2019)

the growth of occupational pensions and private pension plans. The term occupational pensions is used to refer to those private capitalisation pensions that companies offer to their employees through collective or individual agreements. Private capitalisation pensions are those individually taken out through policies with banks or insurance companies.

- The second variable is occupational and private pension plans (measured as a percentage of the capital accumulated above the GDP), which enables us to see a clear division between the capitalisation regimes and the other contributory and universalist regimes. 
- The third variable is the expenditure on pensions, measured as a percentage of the GDP, which also contributes to clarifying the division between the different pension regimes.

- The fourth variable provides us with information on social expenditure, which can contribute to the definition of regimes based on the greater or lesser presence of the State in social protection and in subsidies and transfers.

- Lastly, the fifth variable is the volume of informal employment, which will also help us to classify the pension models because said variable indicates that the countries with a greater proportion of informal employment (such as those of Latin America), have fewer resources for contributory pensions and, therefore, the most likely option is the development of non-contributory pensions and welfarism to tackle poverty. These indicators have been collected for a set of 28 European and American countries.

According to this model, we perform a factorial analysis of chief elements to describe the correlations between the variables considered and to observe the distribution of similarities between the different countries. The correlations observed show us how social expenditure has a positive association with the expenditure on public pensions and with the GDP per capita, and a negative correlation with informal employment, which highlights that informal employment is a serious obstacle for the post-distributive policy. Public pensions correlate similarly; they have a positive correlation with the GDP per capita, which also highlights the importance of the level of wealth to be able to distribute and avail of pensions in a country. The relation between public pensions and informal employment is also negative. The GDP per capita has a negative relation with informal employment, as could be expected.

Our analysis reveals an explained variance of $79 \%$ with the first two factors. Table 14.3 shows the relation between the original variables and the two retained factors, and Fig. 14.1 represents the distribution of the countries in the factorial space. The first dimension $(52 \%)$ is defined by the social expenditure in comparison to informality. Thus, countries with high social expenditure, such as the Scandinavian social democratic countries contrast with the Latin American countries or the countries with low social expenditure and a high level of informal employment. The second dimension $(27 \%)$ reflects high or low levels of private pension plans,

Table 14.3 Component matrix

\begin{tabular}{l|r|r}
\hline \multirow{2}{*}{} & \multicolumn{2}{l}{ Components } \\
\cline { 2 - 3 } & 1 & 2 \\
\hline Informal employment & -0.817 & -0.262 \\
\hline GDP per capita & 0.721 & 0.487 \\
\hline Pensions public expenses (\% GDP) & 0.779 & -0.407 \\
\hline Private pensions plans (\% GDP) & -0.040 & 0.901 \\
\hline Social expenses (\% GDP) & 0.893 & -0.238 \\
\hline
\end{tabular}

Correlations

Source: Cited dates (ILO 2019) and OECD (2019) 


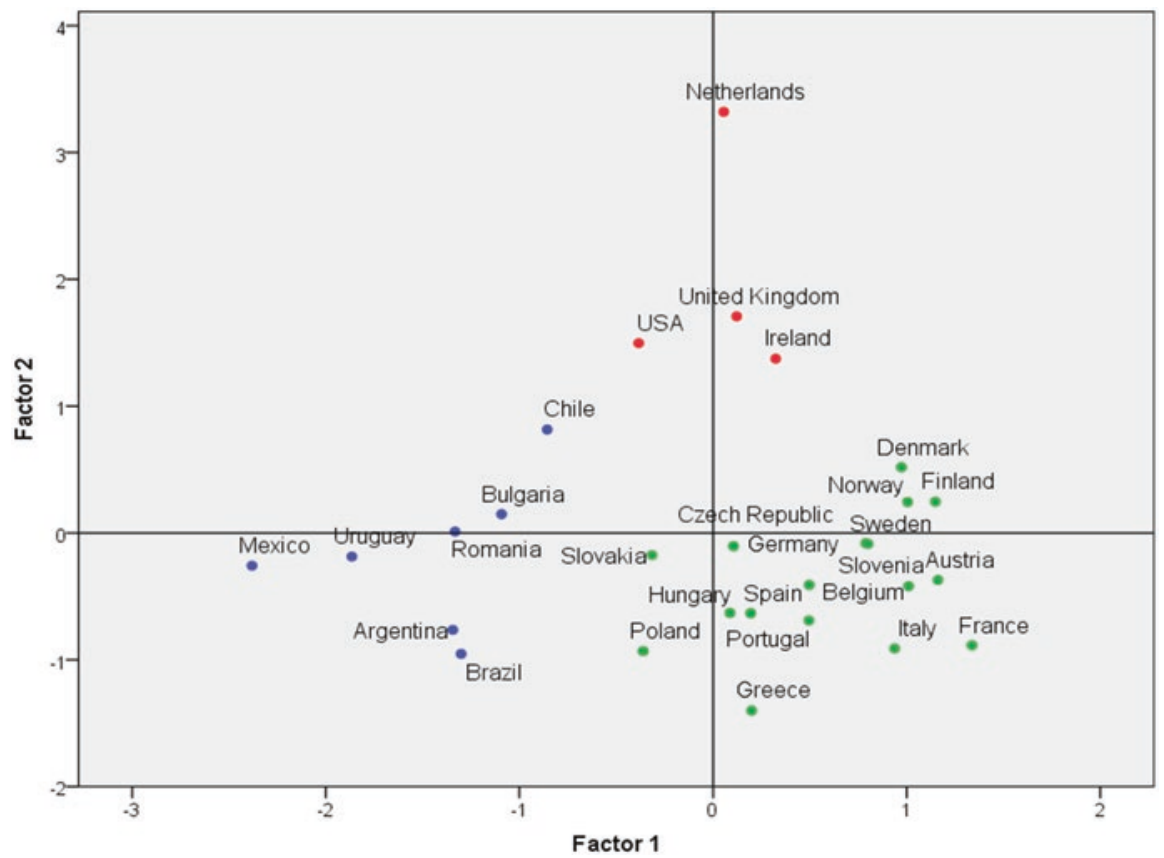

Fig. 14.1 Pensions systems classification by countries. Source: Own elaboration

grouping those countries with private capitalisation regimes at the top, and at the other extreme, at the bottom, those countries with contributory regimes.

Based on the intersection of these two dimensions, Fig. 14.1 shows the distribution of the countries classified into three groups after applying a hierarchical cluster analysis using the Ward method. (1) On the one hand, in the upper right quadrant, the countries with predominantly capitalisation regimes based on occupational and private pension plans appear. In other words, countries considered to have liberal regimes, such as the US (76.3\% GDP), the United Kingdom (104.5\% GDP) and Ireland (31.6\% GDP). In this quadrant, a particular case is the Netherlands $(171 \%$ GDP) as it has a very important occupational pension regime of companies and private individuals, but strictly speaking it cannot be considered a liberal regime because its plans are part of a negotiation tradition (since the beginning of the twentieth century) of Social Partnership, negotiated with the unions, also known as welfare negotiated with the unions (Trampusch 2007).

(2) The lower right quadrant contains the social democratic countries, such as Finland, Sweden, Denmark and Norway, with high social expenditure, high expenditure on pensions and formalised employment. In this group, Denmark and Finland have a moderate percentage of their GDP invested in occupational pension plans and this is a supplementary support to state pensions. It is also a pension plan system negotiated with unions. This group also includes countries with contributory regimes, with high expenditure on pensions and social protection, but with low 
participation in occupational and private pension plans. Austria and Germany are in this group. Below these appear the Mediterranean countries, such as France, Italy and Spain (8.8\% GDP), whose main difference is the scarce participation in capitalisation regimes (that is, in occupational and private pension plans). It can be added that the growth in private pension plans and occupational pensions has been halted by the financial downturn since the European recession, as well as other factors that we will examine below. However, Spain, Greece, Portugal and Italy have a greater proportion of informal employment. Therefore, they may have been forced to make a greater effort to develop non-contributory and welfare pension plans.

Lastly, (3) the lower left quadrant contains the Latin American countries, such as Brazil, Argentina, Mexico and Uruguay, which are part of the group with high informal employment, a low capitalisation pension regime and a contributory system for formal employment, but with weak institutionalisation (Ubasart and Minteguiaga 2017). This group also includes Chile, although it tends to be closer to the first group of liberal countries. This is a group of countries with a strong duality in the pension regimes: the insiders with the contributory system derived from formal employment and the outsiders who are not entitled to access contributory pensions, but possibly with certain welfare protection and non-contributory resources, which correspond to the Latin American model known as a regime of structural heterogeneity.

\subsection{European Convergence in the Reform Policies of the Welfare State}

To date this century, the reform policy of the welfare states in Europe has tended to adopt certain standards of harmonisation or even convergence considering they are facing shared problems, such as the ageing of the population, precarious labour markets, public debt, the financial downturn and the forecast of public expenditure on pensions for the decades to come, in the context of the limits imposed by the Maastricht Treaty in 1992, such as the control of public deficit, public debt and inflation, as well as the limits imposed by the Great Recession (Comisión Europea 2003; European Commission 2012, 2020). Let us take a look at these limits.

\subsubsection{Limits in Policies}

As we have indicated above, governments have seen their room to manoeuvre to finance pensions in each of the four countries studied reduced.

Spain In the case of this country, in 2007 accumulated public debt was relatively moderate (35.6\% of the GDP), but the Great Recession forced it to make a huge effort to cover the unemployment benefit and pensions, in such a way that in 2018 
the accumulated debt represented no less than 97.6\% of the GDP in 2018 (see Fig. 14.2). The reduction in the room to manoeuvre was also reflected in the fiscal deficit, the difference between fiscal income and expenditure. In 2007 Spain still had a surplus of $7.7 \%$ of the GDP as a result of the expansive economic cycle that took place between 1995 and 2007. However, the deficit shot up from $2009(-10.4 \%)$ to $2012(-10.4)$, which were the hardest years of the recession. Since this date it has reduced, but the deficit was still worrying in 2018 ( $-2.4 \%$ of the GDP, see Fig. 14.3). But the pressure is there: the forecast of expenditure on pensions tends to increase towards 2030, as reflected in Table 14.4.

United Kingdom This country was also very affected by the Great Recession. The public debt in 2007 was also moderate (41.5\% of the GDP). Between 2010 and 2013 said debt rocketed until reaching $79.5 \%$ last year, and it continued to increase until $2018(86.2 \%)$. This trend is also reflected in the fiscal deficit. In 2007 it already had a fiscal deficit of $-2.6 \%$ of the GDP. In 2009 the deficit reached $-10 \%$ of the GDP and from that date on it reduced until reaching $-1.3 \%$ of the GDP in 2018 .

Argentina This country, unlike the previous two, experienced moderate growth during the period (see Chap. 2), in such a way that it contributed to reducing its public debt: in 2006 it had a debt of $70 \%$ of the GDP. It managed to gradually reduce it to $38 \%$ in 2011. But from this date onwards, it increased again until reaching $52 \%$ in 2015 and $86 \%$ in 2018. The fiscal deficit has followed a parallel trend: in 2006 it had a slight surplus (1.3\%), and in 2008 again $(0.2 \%)$. From that date onwards, it has grown until reaching $-3.9 \%$ in 2018 .

Chile This is the only country that started with a very low level of accumulated public debt, barely $3.8 \%$ of the GDP, with a fiscal surplus of 7.7 and $4.7 \%$ of the GDP in 2007 and 2008 respectively. But from 2010 onwards, public debt started to

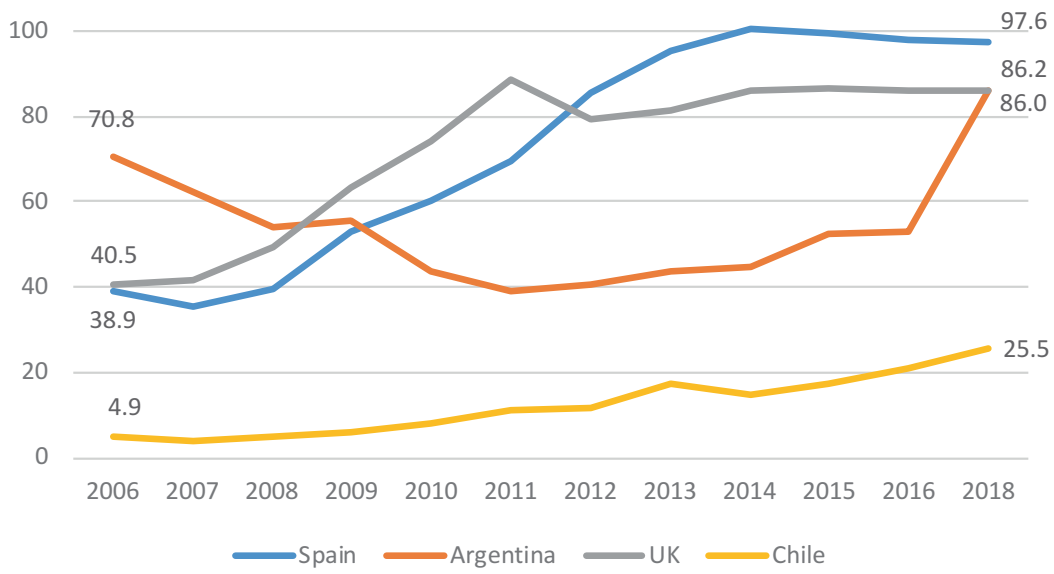

Fig. 14.2 Public debt as \% GDP. Source: Expansión (2020). Datos macro-economicos 


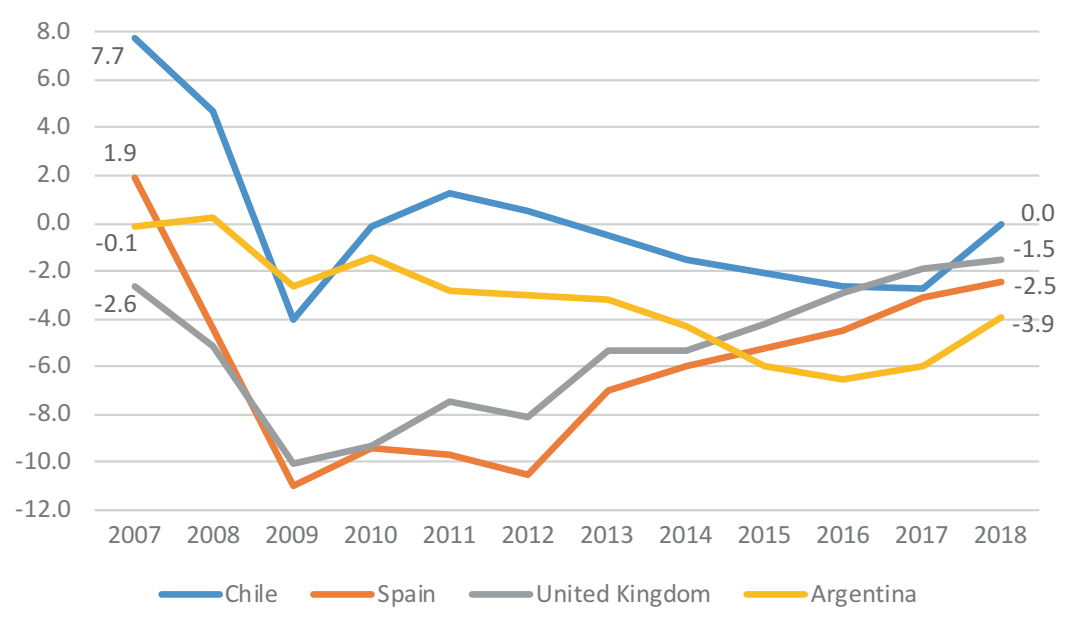

Fig. 14.3 General government fiscal balance as \% of GDP. Source: OECD (2020) and Expansión (2020)

Table 14.4 Projection of social expenditures on pensions (\% GDP)

\begin{tabular}{l|l|l|l|l}
\hline & $2015-2016$ & 2020 & 2025 & 2030 \\
\hline Argentina & 7.8 & - & - & - \\
\hline Chile & 5.1 & - & - & - \\
\hline Spain & 12.2 & 12.3 & 12.4 & 12.6 \\
\hline UK & 7.7 & 7.7 & 8.0 & 8.0 \\
\hline OCDE & 8.8 & - & - & - \\
\hline
\end{tabular}

Source: OECD (2020)

increase from $8 \%$ of the GDP in 2010, to $17 \%$ in 2015 and $25.5 \%$ in 2018 . The fiscal deficit is $-2.7 \%$ of the GDP. In comparative terms, this is the only country-of the four countries compared - that can have some room to manoeuvre to improve social policies.

\subsubsection{Some Shared Elements in the pension reforms}

In international institutions, such as the OECD (2020), certain similar partial reforms can be distinguished in the pensions that could lead to a supposed convergence in the reforms, such as: (1) the rise in the retirement age and the minimum retirement age; (2) incentives to remain longer in employment, after turning 65; (3) restricted early retirement; (4) extension of the coverage of welfare pensions; (5) reduced taxes on low pensions and increase in benefits; (6) diversification of the possibilities of contribution and of obtaining benefits; (7) suspension of adjustments to pensions according to the rhythm of demographic growth of pensioners, among 
other measures. This is a list of possible measures suggested by the OECD (2020), but the measures vary from one country to the next depending on the financial situation of the Social Security, the demographic evolution, the forecast of expenditure on pensions, the government in power, the power of unions and the institutional network. Therefore, we are talking about diversification, as we indicated in the initial hypothesis.

In this regard, we will show the diversity of responses between European countries such as Spain and the United Kingdom (for the case of occupational pensions), or between Chile and Argentina. The same welfare models (contributoryproportional liberal or Bismarckian) do not always seem to adopt the same criteria of reforms.

\subsection{Characteristics and Reforms of the Pension Systems}

In this section we will give an account of the reforms of the pension systems in the four countries treated as specific cases.

\subsubsection{Pension Reforms in Spain: The Toledo Pact}

In the case of Spain, the pension system has been undergoing reforms since 1995. The reform is known as the Toledo Pact and it has been followed by successive subsequent reforms, in 2005, 2006 and 2011. The negotiation of the Toledo Pact has failed as a result of the political deadlock (2015-2020) and the parliamentary insufficiency to implement it. Today, due to the instability in the Spanish Parliament and the strong discrepancies between unions and political parties, it is difficult, but not impossible, to renew the Toledo Pact. However, all the actors positively assess the Toledo Pact, from 1995 to today, because it entailed creating a long-term political commitment between the Right and the Left. This commitment is explained by the nine million pensioner voters conditioning the political vote: no political party can dispense with this huge electoral force. This seems to be a common problem in other European countries, pursuant to the ageing of the population. Another political achievement of the Toledo Pact has been the creation of a Parliamentary Board (which we interpret as strong institutionalisation) and the commitment to negotiate said pact every 5 years.

The chief goals of the Toledo Pact in 1995 and in its successive reforms can be summarised as follows (De la Fuente et al. 2018):

- To raise employees' contribution to the Social Security to access pensions. It has gone from 2 to 15 years in recent decades and now the calculation of the whole work life is being discussed, although it is difficult to come to an agreement on this point as a result of the contributory shortages of many workers. 
- The second achievement has been the fight against the underground economy and the persecution of fiscal fraud in order to improve the financing of retirement pensions, unemployment protection and Social Security.

- The third objective was to delay the "de facto" retirement age. The legal age was 65 until the 2011 reform. However, the average de facto retirement age is 63.3, since many large companies use early retirement to restructure their staff. Part of the early retirement is covered by unemployment benefit and part is paid by the company until the employee reaches 65 . From that age onwards the pension is covered by the Social Security. The last pension reforms in 2013 sought to extend the formal retirement age to 67.5 . This goal will be reached gradually.

The current discussion of the reform of the Toledo Pact includes, with a narrow margin of consensus, the following objectives; (1) Extension of the legal retirement age: $65-67.5$ (measure already passed by the government). The person must have contributed for 38.5 years to obtain $100 \%$ contributory pension. The progressive application would culminate in 2027; (2) Encourage delayed retirement (for every year delayed -65 years - the future pension increases by $2 \%$ ); Increase the number of years in the calculation basis from 35 to 37 years for maximum pension for those born after 1957; the minimum number of years of contribution will be 15 , to receive $50 \%$ of the pension; (3) The elimination of the Sustainability Factor (introduced in the 2011 reform) is being discussed, which entails an adjustment as the population ages, in such a way that 5\% more life expectancy reduces the initial pension by $5 \%$ (this was to come into effect in 2019, but the socialist government froze this measure this year).

In 2011 the Assessment and Reform Report of the Toledo Pact, published by the Ministry of Employment, defended the need to reach a financial balance, as claimed by the European Union. To do so we must diversify sources of finance, increase the Reserve Fund, guarantee contributory pensions; prolong work life due to the ageing of the population and because of life expectancy; mobilise and guarantee the integration of women into the workforce; protect the most vulnerable groups: widow and orphan benefits; fight against fraud and the underground economy; strengthen the principle of "contribution"; promote complementary systems through tax allowances; legally channel migratory flows to avoid social dumping.

The fourth objective, achieved in the first Toledo Pact in 1995, was the funding of non-contributory pensions, through general state budgets. This affected a large number of housewives (Martín Artiles and Molina 2015).

Fifth, flexibility in the retirement age was another seemingly important achievement of the first pact. This consisted of the possibility of a person aged over 60 being able to partially retire with a part-time work day, and a younger person with a hand-over contract would take their place. But this measure has not been very successful. Lastly, another important achievement was creating a Reserve Fund for pensions, provided in 2005 with 23 billion Euros, which would act as a buffer in periods of crisis; effectively this is how it was used during the economic recession from 2008 onwards, and today it has been practically fully spent. 
In February 2011 a tripartite agreement was made between the socialist government, the Confederation of Employers and Industries of Spain and the Comisiones Obreras and Unión General de Trabajadores trade unions. The Social and Economic Agreement is still in force. In it, the parties committed to economic growth, employment and the guarantee of pensions, as well as the progressive increase of the calculation base of the contributions from the last 15 to 25 years of work life, to obtain $100 \%$ of the pension.

Likewise, in November 2013, the Popular Party (PP) government unilaterally passed a basic reform that affects the revaluation of the pensions, up to then indexed in the Consumer Price Index (CPI), consisting of: (1) The revaluation index (from a minimum of $0.25 \%$ to a maximum of $0.5 \%$ of the CPI); (2) The Sustainability Factor, linked to demographic criteria, involves a reduction in the average pension as life expectancy increases. But with the change to a socialist government this Sustainability Factor has been frozen and the price index has been applied again in 2020.

Individual pension plans and occupational capitalisation pensions, both considered to be complementary pensions, have received a certain boost in recent years. This is precisely one of the goals of the European Union to diversify the sources of funding of the pensions. But these pensions have not had the success, or the importance they have in Anglo-Saxon countries. There is a considerable difference between Spain and the United Kingdom. The occupational pension systems have not been successful in Spain, France or Italy, despite it being a policy suggested by the European Union and its Multi-pillar Welfare State project. The Negotiated Occupational Welfare State does not fit well with countries with many small companies, due to the weakness of the representation of unions and employers, the weakness of the collective negotiation and the scarce participation of workers in production profits. For this reason, in Spain there are limited negotiated pension plans in large companies, while the centralised and generally effective collective negotiation system (erga omnes) covers all workers (80\%) with the force of the law (Martín Artiles et al. 2016).

\subsubsection{Trends in the United Kingdom}

The majority of current debates about the pension system in the United Kingdom are conceived in the context of the growing concern for the ageing of the population and the financial sustainability of pensions, on the one hand, and the political responses which since the 1970s have been inspired by the neoliberal ideology that questions the cost of the ageing of the population and the role of the State in providing pensions, on the other (Foster 2017; Grady 2016; Naczyk 2018). The Office for National Statistics (ONS 2015) estimates that the population aged above 65 in Great Britain will grow twice as quickly as the population of working age, representing almost one quarter of the population by 2037, with the consequent changes in the proportion of contributors to the pension system compared to beneficiaries of the 
system. This represents a fundamental challenge for the future sustainability of pensions in the United Kingdom (Hofäcker 2015).

Pensions in the United Kingdom are a complex and mixed system. They can be classified into three groups: (1) state pensions, which can be the "basic state pension" and "second state pension" (S2P); (2) private occupational pensions, which can be "defined benefit pensions" and "defined contribution pensions"; and (3) individual/personal private pensions, which can be pensions of interested parties (stakeholders' pensions), and self-invested personal pensions.

This section will focus on the first two pension groups due to their greater relative importance within the system. We will begin with state pensions. The modern basic state pension, known as the "Old Age Pension", was introduced in Great Britain in 1909 under the Old-Age Pensions Act 1908 and it was aimed at preventing poverty in people's old age. It was the first step towards establishing a Social Security system with unemployment benefit and healthcare, introduced through the National Insurance Act in 1911, which was established with the creation of the British Welfare State in the period following the Second World War. State pensions are financed through contributions to the National Insurance, related to income, and participation in the system is compulsory.

There is agreement that the most important change that took place in state pensions since the 2007-2008 financial downturn is the implementation of the new single tier state pension. From 2016 to 2017 onwards, the basic state pension and the second state pension were replaced by a new single tier state pension for all those people below retirement age. The Department for Work and Pensions of the United Kingdom introduced this change in a rather euphemistic manner: "The creation of the single tier pension will essentially reform the state pension system. It is designed in the light of a modern society, with a clearly defined function: to provide the bases to support people who are saving for their retirement" (DWP 2013: 27). In short, the proposed system eliminates the second state pension that had offered a top-up, related to income, on the basic state pension based on the nominal social security (Berry 2016). The main difference that exists between the previous versions of the system and the new proposed system is that it will not be essentially universal, with a greater possibility of authorising unpaid activities than was possible in the past.

However, from a more critical perspective, Berry (2016) rightly points out that by redefining the purpose of the state pension as a means for individuals to save for retirement, the reform is a subtle way of reducing social welfare via which the State withdraws from any attempt to provide a true income-replacing benefit for pensioners, instead of providing a context in which individuals can become self-sufficient and silently contribute more to the system. According to the opinion of some academics, this is another expression of the "financialisation" process of the social welfare benefit in the United Kingdom, which started in the 1970s and has intensified since the financial downturn and the implementation of austerity programmes (Berry 2016; Langley 2008). In the case of pensions, financialisation refers to the notion of policy according to which "individuals [not the State] must assume the personal responsibility of their own long-term financial security" (Berry 2016: 1). 
As we will see, financialisation is also a characteristic observed in the (private) occupational pension system and it is the rationality that explains the greatest change that has taken place in this system with the introduction of "automatic registration".

In the United Kingdom, occupational pension plans are agreements established by employers of all sizes to provide pensions (and other benefits related with the workplace) to their employees. These were created by virtue of the Pension Schemes Act 1993, the Pensions Act 1995 and the Pensions Act 2008. Occupational pension plans are financed through a combination of contributions from employers and employees. Therefore, although employers and workers contribute, they are essentially capitalisation plans. Employers' contributions generally represent a greater proportion of total labour costs than employees' contributions. These pensions are financed through contributions of at least $8 \%$ of the employees' gross salaries, with at least $4 \%$ paid by the employee, $3 \%$ by the employer and $1 \%$ by the State through a reimbursement in national security contributions. Due to the decentralised nature of collective negotiation in the United Kingdom, the large majority of occupational pension plans are offered at company level (Naczyk 2018: 85-86).

'Occupational welfare' has a longstanding history in the United Kingdom dating back to the nineteenth century with the establishment of charity associations that granted rights to benefits for illness, accidents and deaths, as well as old age and unemployment benefits, but which, nevertheless, excluded the lowest strata of the labour force (Harris 2004). Occupational pensions are prior to statutory pensions. Until the 1970s, occupational pension plans, which were quite 'generous' and were barely regulated by the state, essentially favoured qualified workers who employers, through their contributions to the system, wanted to retain; with "early leavers" (workers who were going to be dismissed) effectively subsidising the pensions of the end salary of permanent 'white-collar' workers (Naczyk 2018: 84).

Occupational pensions started to change dramatically with the establishment of individual/personal pensions in 1988 (the third pension group in the initial classification) by Margaret Thatcher's government, following the enactment of the Social Security Act in 1986. According to Pierson (1994), these laws afforded workers the possibility of changing their occupational pension or second state pension and signing a new pension plan (actually a personal investment plan) with other private service providers, such as insurance companies, banks and building societies and unit trusts.

In 2015, there were more than 6000 professional regimes in the United Kingdom, of which 5000 were in deficit. The employers tended to offer their employees access to an occupational pension plan with defined benefits, generally based on the end salary, in other words, usually the employee was promised a pension of a fixed proportion of his/her salary calculated at the time of retirement. With the increase in the longevity of the population and the drop in interest rates, this scheme gradually became unsustainable, and many employers started to exclude new employees from the scheme of defined benefits as well as those who were offered pensions of defined contributions. Under this agreement, the employer (and sometimes the employee) 
makes regular payments to a private pension fund, and the fund is used to buy a pension when the employee retires (DWP 2010).

The most important change that has occurred with the occupational pension plans since the financial downturn is the introduction of the "self-registration" system in 2018. The Pensions Act of 2008 stipulates that, from 2018 onwards (depending on the size of the company), all employers will be entitled to automatically self-register their workers in occupational pension plans, thereby transferring more responsibility to employers to guarantee that their employees are registered in the business plan. Those workers who do not want to be registered will have to 'opt out' of their employer's occupational pension plan, instead of 'opting in' as was the case in the past.

The gradual introduction of the new system sought to eliminate the inequalities in accessing the system, for example, between occupational categories, company size and sectors of activity. The chief inequality is the gap existing between public sector employees, among whom membership of the system reached $87 \%$ in 2014 , and private sector employees, with only 49\% the same year (Naczyk 2018; ONS 2015). In 2014 the average membership in the United Kingdom was 59\%. The key question from the perspective of this chapter is that the new 'self-registration' system introduced to expand the occupational pensions, guarantees that the majority of people employed save into a 'private' pension plan, in addition to the state benefit to which the person is entitled (Berry 2016). This analysis is consistent with the hypothesis of the financialisation (Watson 2009) of the pension system presented above, in which individuals, not the State, assume greater responsibility for their own financial security; this can also be observed in other areas of British social policy.

\subsubsection{Characteristics of the Reforms in Chile}

In order to present the specific characteristics of the reforms and re-reforms of the social welfare systems in Argentina and Chile from 2008 to date, it is important to note that both countries were categorised as belonging to the group of pioneering countries with Uruguay and Costa Rica, since their welfare systems compared to other countries on the continent were established between the second and third decade of the twentieth century, between 1919 and 1930 (Mesa-Lago 2000). ${ }^{6}$

Considering the historical evolution of the Chilean welfare system, Arenas de Mesa (2010) defines a first stage between 1924 and 1950 based on five pension funds which grouped together in the first three the majority of dependent workers, and in the two remaining funds, the Armed Forces and the police. For the 1950s, the pension system was characterised by the coexistence of a multiplicity of regimes

\footnotetext{
${ }^{6}$ Specialists qualified the Latin American countries in three groups: pioneering-high, intermediate and late-low. In general, the conditions of access to pensions were liberal especially in the pioneering-high group. This author points out that "said systems suffered stratification, high costs, an increasing deficit, financial and actuarial imbalance" (Mesa-Lago 2004: 13 \& 19).
} 
(150) and by institutional atomisation ( 35 funds). In the second stage, starting in the 1970s, the system sought to converge with the standardisation guidelines formulated in the Beveridge Plan. For this decade, Chile had one of the most advanced systems: it covered all the contingencies, it presented high coverage and afforded generous benefits. However, to characterise the system of this period we use the metaphor of Mesa-Lago who referred to this as a bureaucratic labyrinth, legally complex and stratified, which was incubating considerable inequalities and suffered financial and actuarial imbalances.

The third stage refers to the reform leading to replacing the distribution system with a capitalisation system during Pinochet's dictatorship in 1981 (Decree Law 3500 and 3501). In Chile the welfare reform replaced the distribution system of defined benefits with a compulsory individual capitalisation system, of defined contributions, paid for by the workers into a personal retirement account and managed by private anonymous associations: the Pension Fund Managing Companies (AFP). ${ }^{7}$

One of the characteristics of this system is that not only is any idea of social solidarity - the fundamental principle governing distribution systems - lost, but, in the capitalisation system of individual accounts, the AFP become managers of the accumulated funds. Some authors highlight that the essential characteristic of this new system is that the contribution is only made by the worker, freeing the private company of any contribution. In 2002 a reform was introduced which allowed five pension fund options to invest through individual accounts; under this option the member could choose the type of investment and level of risk in which their funds could be used. The introduction of multi-funds meant pension managers became important actors in local and financial markets. According to Mesa-Lago (2009) the impact of the intervention of these AFP in the Chilean economy meant that 28 years would pass, in democracy, before establishing the reform of the welfare system in 2008 .

In addition to the problems highlighted by the ILO, such as the lack of solidarity and coverage, gender inequality and the lack of representation of insured parties, countless diagnoses have reflected the increasing inequality that said pension system introduced into Chile; among those most mentioned there are not only the changes of parameters of the contributory conditions to retire, but the use of a life expectancy table differentiated according to sex is indicated, as well as the use of a complex calculation methodology which lays the foundations of unequal treatment for women (Yáñez 2010). In general, there is a serious coverage problem for those developing independent activities, leaving more than half of retired people in conditions of vulnerability and poverty.

The re-reform of the welfare system introduced during Bachelet's government in 2008 , can be summarised in the return of the role of the State as guarantor of a

\footnotetext{
${ }^{7}$ The establishment of the retirement system freed the employer from making contributions to the employee's individual account. Furthermore, the roles of the market and the State in the management of pension systems also changed, assigning the former their financial management, and the latter their regulation and supervision, as well as the focused and welfare relief of old age poverty (Uthoff 2008).
} 
certain conception of universal rights and the creation of the Solidarity Pension System (SPS) which, via a new public institutionality, would implement measures to increase the welfare coverage of vulnerable groups such as youths, women ${ }^{8}$ and independent workers. Following the international indications during Bachelet's government, a commission was created for the analysis of the welfare reforms representing wide social sectors seeking the legitimacy of same.

Although the reform persists in sustaining the individual capitalisation system of the former Pinochet regime, a series of changes are introduced which mean not only the reduction of costs, but also achieving better pensions for members, as well as strengthening the Voluntary Welfare Savings (APV). The conditions to access basic solidarity pensions (PBS) and the Solidarity Welfare Contribution (APS) include requirements such as being part of the $60 \%$ of the population with lower incomes and having spent a minimum period of 20 years in the country including four out of the past 5 years, and having turned 65 both for men and women. ${ }^{9}$ The reform has led to a new institutionality that establishes the Pension Reserve Fund (FRP), with an initial contribution of 60.45 million dollars at the end of 2006 .

Regarding said reform, some analysts highlight its benefits since for some it is an "integral system" that reconciles the contributory dimension with the noncontributory dimension and consolidates the role of the State, while gender and age inequalities are adjusted for young people (Arenas de Mesa 2010). For other analysts, the system follows an unbalanced logic because this new "solidarity" state pillar is too similar to social welfare and jeopardises the celebration of the re-reform (Birgin and Pautassi 2001). Or from a much more dissatisfied perspective, such as that of Soto Pimentekl (2015), the reform perpetuates a neoliberal retirement model that operates according to the principles of equivalence, focalisation and centrality of the market, with SCI and the capital market being the distribution mechanisms, through their free operation via their own rules.

In any case, some authors highlight the introduction of the non-contributory element of financing with fiscal resources, under the objective of guaranteeing the welfare protection of all those people excluded from the private contributory system (Yáñez 2010: 20).

\footnotetext{
${ }^{8}$ The subsidy for saving for old age in two groups at greater risk as regards their pension savings funds: women and young people. The law establishes a subsidy for working women, through the "child allowance", and for young people, through the "youth employment subsidy". In both cases, a sum of money is placed in the pension savings account (Soto Pimentekl 2015).

${ }^{9}$ The APS is a supplementary payment in addition to self-financed pensions from the private system. It is granted to all pensioners who receive pensions lower than a minimum sum established from 1 September 2009 at 150,000 Chilean pesos. This sum gradually increased until 2012 when it reached 255,000 Chilean pesos per month, the equivalent to approximately 150 dollars per month at an exchange rate of 500 Chilean pesos per dollar (Yáñez 2010: 21).
} 


\subsubsection{The Welfare System in Argentina}

The Argentinian welfare system evolved from the beginning of the twentieth century to 1946 through pension funds for each sector with a similar result to Chile in terms of its fragmentation, the unequal conditions of access, and sums of contributions and benefits (Panigo and Médici 2013). In the mid-1940s the system extended to all workers until 1969 when it was unified and began to be governed by the National Social Welfare System (SNPS).

In the mid-1980s, diagnoses weighted a range of factors referring to the financial sustainability problems of the SNPS; among these, analysts pointed out the drop in real salaries in inflationary conditions and the subsequent increase in unemployment after the collapse of the occupation structure towards informality; with a growing expansion in the services sector and in self-employment; the growing degree of informality added to the old problem collection bodies had to oversee the activities of self-employed people or independent professionals (Lo Vuolo 2008). The diagnoses also weighted the weight of the aging of the population, the direct impact of which affected the support rate (active/passive relation) and the exhaustion of the welfare surplus, considering its use for financing state functions other than social welfare. All of these variables made it impossible to meet the legal defined benefit parameter of the pension credit equivalent to $82 \%$ of the salary of a worker in activity in a similar position (Bonari et al. 2009).

In a context of complicated legislative and union negotiations, in 1994 two changes occurred. One was an important change regarding the age parameters to access the pension and another one regarding the necessary years of contribution. The retirement age increased from 55 to 60 for women and from 60 to 65 for men. Furthermore, the requirement to contribute more years to the system increased from 20 to 30 years of contribution. In addition, Law 24.241 introduced the option to retire in one of the two pension systems, distribution or capitalisation. On the one hand, a tripartite public distribution system, managed by ANSeS (National Social Security Administration) and, on the other hand, an individual capitalisation regime, managed by Retirement and Pension Fund companies, known as AFJP. The coexistence of both systems, distribution and capitalisation, led to a mixed social welfare system.

In this way, the State guaranteed a minimum contributory pension perceived as the Universal Basic Benefit (PBU) via which similar defined benefits were granted to all insured parties, according to age and years of contribution. Furthermore, via private capitalisation, an additional pension was paid. Both contributory options operated in addition to a non-contributory pension system. But the mixed system imploded with the severe financial downturn in 2001, and despite adjustments and partial modification since 2003, the system was reformed again in 2008.

Following the severe socio-political and economic crisis in 2001, a social redistribution was promoted, implementing non-contributory social protection policies. The aim was to universalise pensions for elderly adults who have not contributed the sufficient number of years to the distribution system. In this regard, it is important 
to note the way in which the idea of work informality has no longer been problematized as a voluntary choice of workers but as a problem in the application of macroeconomic policies. That is why it is considered a reparatory measure, as it compares formal workers with informal workers (Hopp and Lijterman 2019).

The welfare re-reform of 2008 (Law 26.425) entailed the end of the mixed system implemented in 1992, withdrawing the private capitalisation system, and returning to the state distribution system. From January 2009, all members were transferred to the public distribution system SIPA (Argentinian Integrated Welfare System) managed by ANSeS with the transfer of funds from individual AFJP accounts to the Sustainability Guarantee Fund. Known as the Welfare Inclusion Plan or Programme, the strategy to extend the welfare coverage through early retirement programmes or moratoria helped to rectify and increase the number of beneficiaries. The Welfare Moratorium granted a pension to all adults of retirement age in December 2004, who did not have the required 30 years of contribution, through the implementation of a monthly discount of the missing contributions. A second strategy, complementary to the previous one, was the offering of early retirement which enabled those who were less than 5 years from retirement or were unemployed (but had contributed to the system, although the years of contribution were not complete), to receive $50 \%$ of the pension.

\subsubsection{Comparative Summary}

Summarising the compared models, we observe that:

The first substantial difference between Europe and Latin America lies in the degree of institutionalisation of the pension systems. In Europe, the institutionalisation is strong, it is linked to rights and duties, to citizens' rights and with the contributory control of employment in social security, there are fiscal sanction regimes. In America, on the contrary, the high volume of informal employment undermines the social protection institutions (Table 14.5).

1. Contributory pensions in Spain are the main protection system for pensioners, but they have financial sustainability problems because new jobs have low salaries and because of the high number of temporary contracts. There are also political difficulties to renew the Toledo Pact agreements. One of the chief problems lies in the low salaries in new jobs-created during the European recession and afterwards-for young people. One of the paradoxes is that the average pension paid is above the average salary of the new jobs, which is a serious problem for the future. For example, in 2017 the average gross salary was lower (1271.88 Euros) than the new average retirement pension (1318.47 Euros), which threatens the sustainability of the pension system: a true intergenerational solidarity 
Table 14.5 Pension systems

\begin{tabular}{|c|c|c|c|c|}
\hline & Spain & UK & Argentina & Chile \\
\hline $\begin{array}{l}\text { 1. Contributive } \\
\text { pensions }\end{array}$ & $\begin{array}{l}\text { Most important } \\
\text { system }\end{array}$ & $\begin{array}{l}\text { Mixed. Public system } \\
\text { financed by taxes and } \\
\text { complementary } \\
\text { Occupational and } \\
\text { private pension of } \\
\text { capitalisation }\end{array}$ & $\begin{array}{l}\text { Public } \\
\text { fragmented }\end{array}$ & $\begin{array}{l}\text { Not at all } \\
\text { System of } \\
\text { capitalisation } \\
\text { Atomisation }\end{array}$ \\
\hline $\begin{array}{l}\text { 2. Gross } \\
\text { replacement } \\
\text { rate Public and } \\
\text { Private }\end{array}$ & $72.3 \%$ & $43.5 \%$ & $83.7 \%$ & $36.2 \%$ \\
\hline $\begin{array}{l}\text { 3. Age of } \\
\text { retirement }\end{array}$ & $\begin{array}{l}\text { Modified } 65 \text { up to } \\
67.5 \text { years in } 2027\end{array}$ & $\begin{array}{l}\text { Modified } 65 \text { years up } \\
\text { to } 68 \text { in } 2034\end{array}$ & $\begin{array}{l}65 \text { years men } \\
60 \text { years } \\
\text { women }\end{array}$ & $\begin{array}{l}65 \text { years men } \\
60 \text { years } \\
\text { women }\end{array}$ \\
\hline $\begin{array}{l}\text { 4. Gender } \\
\text { Inequalities }\end{array}$ & $\begin{array}{l}\text { Composition effect } \\
\text { in labour market } \\
\text { New system for } \\
\text { calculation of } \\
\text { women's } \\
\text { contributions: } \\
\text { improving more } \\
\text { equality }\end{array}$ & $\begin{array}{l}\text { Composition effect in } \\
\text { labour market }\end{array}$ & $\begin{array}{l}\text { Composition } \\
\text { effect in labour } \\
\text { market }\end{array}$ & $\begin{array}{l}\text { Composition } \\
\text { effect in labour } \\
\text { market }\end{array}$ \\
\hline $\begin{array}{l}\text { 5. Occupational } \\
\text { pensions }\end{array}$ & $\begin{array}{l}\text { Weak, it is } \\
\text { important only in } \\
\text { big companies }\end{array}$ & $\begin{array}{l}\text { Very Important at plant } \\
\text { level }\end{array}$ & Weak & $\begin{array}{l}\text { Important at } \\
\text { plant level }\end{array}$ \\
\hline $\begin{array}{l}\text { 6. Private } \\
\text { pensions }\end{array}$ & Very weak & $\begin{array}{l}\text { Important } \\
\text { Mixed: Public, Private }\end{array}$ & Weak & $\begin{array}{l}\text { Important. } \\
\text { System of } \\
\text { capitalisation }\end{array}$ \\
\hline $\begin{array}{l}\text { 7. Negotiated } \\
\text { Welfare }\end{array}$ & $\begin{array}{l}\text { Pick level } \\
\text { Agreement since } \\
\text { 1995. Pacto Toledo }\end{array}$ & $\begin{array}{l}\text { Only at company and } \\
\text { sectoral level }\end{array}$ & $\begin{array}{l}\text { At sectoral } \\
\text { level }\end{array}$ & $\begin{array}{l}\text { Only at } \\
\text { company level }\end{array}$ \\
\hline $\begin{array}{l}\text { 8. Informal } \\
\text { employment } \\
\text { effect }\end{array}$ & $\begin{array}{l}\text { Minimum } \\
\text { non-contributive } \\
\text { pensions (Lismi) } \\
\text { Neo- } \\
\text { assistensialism }\end{array}$ & $\begin{array}{l}\text { Low } \\
\text { Neo-assistensialism }\end{array}$ & $\begin{array}{l}\text { Neo- } \\
\text { asistensialism }\end{array}$ & $\begin{array}{l}\text { Barrier in } \\
\text { system of } \\
\text { capitalisation } \\
\text { Neo- } \\
\text { assistensialism }\end{array}$ \\
\hline
\end{tabular}

Source: Own elaboration

crisis. ${ }^{10}$ This is a similar problem in Argentina. Currently, new salaries are lower than retirement pensions. In other words, new salaries are not sufficient to support the fiscal pressure entailed by pensions, which threatens to render the pension system unsustainable or to seek new financing options, such as the idea of the Multi-pillar State. However, these changes arise again in the Argentinian debate, especially with the commitments made due to debt with the IMF which advises labour, fiscal and pension reforms.

\footnotetext{
${ }^{10}$ The response to this problem has recently, in January 2020, been a rise in the minimum interprofessional salary by decree of the socialist (Podemos) government.
} 
2. The net replacement rate ${ }^{11}$ of public and private pensions is one of the reforms that threatens the purchasing power of pensioners. The replacement rate according to the contributions paid to public and private regimes is proportionally high in Argentina (83.7\%) and in Spain $(72.3 \%)$, that is, in the regimes where the Bismarckian contributory-proportional system dominates. On the contrary, it is very low in the United Kingdom (43.5\%) and in Chile $(36.2 \%)$, where private capitalisation pensions dominate.

3. The retirement age is being extended in Spain; with the last reform it began a progressive increase from 65 years to 67.5 in 2027. In the United Kingdom it has gone from 65 to 68 to be reached in 2034. In Argentina it has not changed since 1994. In Chile the retirement age is 65 . This may be an important matter in the years to come as a result of the increase in life expectancy and the fostering of "active aging" policies.

4. Another problem is the gender inequality among pensions, which can be explained by the composition effect of the job and the discontinuous trajectories in women's careers, a problem shared in all the countries. In the same way, gender inequalities related to pensions are debated in both continents.

5. Occupational capitalisation pensions are important in those countries with a neoliberal political tradition, such as the United Kingdom and Chile, typical models of the financialisation ideology. In these two countries the occupational and private pension funds have financial sustainability problems, both due to their fragmentation and due to the low yield of the capitalisation funds in a long context of low types of financial interest. In the case of Chile, there is a social movement to return to the public pension funds guaranteed by the State. In the case of Spain, occupational pensions have not been successful, despite being included in the Toledo Pact in 1995 and in the consecutive years. The financial downturn has halted its growth since 2007, due to the reduction in profitability of the financial capital. Therefore, there is no convergence between Spain and the United Kingdom. The well-known convergence in some fora is only rhetorical as a political discourse (OECD 2020). The reality is that in Spain the State covers the deficits through special taxes. Moreover, the trend towards capitalisation systems encounters an obstacle in the growth of informal employment in the countries in Latin America. As was discussed in Chap. 2, the informal sector has been growing considerably for decades, partly due to work flexibilisation, typical of the neoliberal policies applied in the region.

6. Individual private pensions are equally important in liberal countries such as the United Kingdom and Chile, ideal type models of financialisation capitalism; this is not the case in Spain and Argentina.

7. Negotiated Welfare, according to Trampusch (2007) is only important in the United Kingdom and somewhat in Chile. This model is inspired by the principle of the individual right of the insured party, rather than on the ownership of the social rights of citizens. In Spain, the inclusion of pensions in the collective

11 "The net replacement rate is defined as the individual net pension entitlement divided by net preretirement earnings, taking account of personal income taxes and social security contributions paid by workers and pensioners." See, http://oe.cd/pag. (OECD 2020). 
negotiation is only registered in large companies; occasionally, pension plans are registered for small socially insured companies. But an important difference compared to other countries is the social agreement (pick level) reached with the Toledo Pact. The Toledo Pact has a profound political meaning in terms of legitimisation of the Bismarckian contributory-proportional model, based on interclassist vertical solidarity. In addition, the social pact props up social order, demonstrating the importance of unions.

8. Lastly, informal employment presents an access problem for workers to their future pensions. In the United Kingdom informal employment is not of great importance. In Spain it is relatively moderate and the solution is the providing of a minimum pension. The majority of those who receive it are women. In Chile and Argentina informal employment is a serious barrier that hinders access to capitalisation pensions. A response to the problem of informality, of precariousness in employment and of the working poor is the growth of neo-welfarism. Neo-welfarism appears to be a generalised trend in the four countries to help severe poverty, which is often in addition to voluntary assistance, religious institutions and NGOs; hence the growth of the third sector.

\subsection{Conclusions}

As regards the general hypothesis, we have shown that the United Kingdom and Spain share reforms inspired by the idea of the Multi-pillar state, which promotes occupational welfare via capitalisation. However, the evidence shows us that actually the two countries are very distant from each other. In the United Kingdom occupational welfare via capitalisation is very important, while in Spain it is relatively insignificant. But it is part of the political discourse on the sustainability of the welfare state, although a rhetorical discourse, despite being included in the Toledo Pacts. In a certain way, as pointed out by Adelantado and Calderón (2005), we are facing the same (rhetorical) response to similar problems, but in our opinion the results are different. In practice, in Spain, unions defend the traditional contributory-proportional public system, which continues to be important as an inter-classist means of solidarity, although questioned by the crisis of inter-territorial solidarity. The political right has seen how the sustainability of the welfare state is an important market of votes in the elections. Neoliberal policies have been applied more in the labour market (flexibilisation) than in the welfare state.

Argentina and Spain share a contributory-proportional pension system, also inspired by the corporate model, with the participation of unions and employers which defend the well-known Bismarckian model. Although in the Argentinian case it is burdened by the high volume of informal employment and the low institutionalisation of the pension systems, which hinder inter-classist solidarity due to the strong dualisation of its labour market (insiders, with formal work/outsiders with informal work). In Chile, the pension system via capitalisation is very fragmented, 
representing a much more unequal and neoliberal system, which highlights an individualised model with low solidarity. But today this is highly contested by a social and union movement that defends solidarity through the role of the state.

\subsubsection{Final Discussion}

The analysis of the four countries shows that in a certain way there are similar discourses (spill over effect), but with different contexts and policies according to the society and institutional context, the government, the power of unions, social movements, but also the demographic context. As a consequence, the reforms have not been uniform. But there are underlying ideological trends which drive the reforms towards a multi-pillar model. These trends, as we will explain below, are: (1) the organic solidarity crisis; (2) the inter-classist solidarity crisis; (3) the intergenerational solidarity crisis and (4) the inter-territorial solidarity crisis. We could state that the trends of the reforms are conditioned by these four solidarity crises.

First, we can discuss the "organic solidarity" crisis, which appears in the reconstruction of the former "mechanic solidarity", such as mutual support, inter-family help and voluntary help. This is giving rise to the development of territorial solidarity policies and the growth of the third sector, which has been called "second welfare" by some authors (Pavolini et al. 2013).

Second, we can visualise the inter-classist vertical solidarity that has led to the rejection of fiscal pressure and to claims to reduce taxes, which has been driven particularly by liberal, conservative and even social democratic parties. In response to this, individualist values and meritocracy have increased; those with higher incomes reject the rise in taxes. A reflection of this is the trend towards the transformation of language, in such a way that we have gone from 'citizens' rights to the rights of the insured party" (Antón 2009).

Third, inter-territorial solidarity also went into crisis after the 2007-2008 financial downturn. The growth in nationalism and regionalism in many European countries has caused a rejection of the transfer of resources between rich and poor regions, between countries from the north, greater contributors to the coffers of the European Union, and those from the south of Europe.

Lastly, another element is the inter-generational solidarity crisis. Salary devaluation during and after the Great European Recession has affected the salary incomes of young people, and the quality of their employment. An example of this is the "working poor": workers who are poor despite having work, have increased in Europe.

In short, after presenting the characteristics of the systems in Chile and Argentina and observing the trends towards occupational pensions in Spain and the United Kingdom we believe that it is essential that whatever welfare reform is implemented, this must be publicly and widely discussed, seeking maximum consensus through commissions that adequately represent the sectors involved. Publicity of the debate is important for citizens' education, as well as to legitimise the reforms, so that 
different future governments do not undermine that which has previously been achieved (Mesa-Lago 2004: 100).

Acknowledgements We would like to thank José Adelantado and Pedro López-Roldán from the Autonomous University of Barcelona and Sandra Fachelli from the Pablo Olavide University for their comments.

\section{References}

Adelantado, J., \& Calderón, E. (2005). Globalización y Estados del Bienestar. Respuestas semenjantes a problemas parecidos. Cuadernos de Relaciones Laborales, 23(2), 15-44.

Adelantado, J., \& Calderón, E. (2006). Globalisation and the welfare state: The same strategis for similar problems? Journal of European Social Policy, 16(4), 374-386. https://doi. org/10.1777/0958928706068275.

Antón, A. (2009). Debates sobre las ideas de la izquierda. Madrid: Talasa.

Arenas de Mesa, A. (2010). Historia de la Reforma Previsional Chilena: Una Experiencia Exitosa de Política Pública en Democracia. Santiago de Chile: Oficina Internacional del Trabajo - OIT.

Arnsperger, C. (2005). L'État social ctif comme un noveau paradigme de justice sociale. In Vielle, P. et al. Op cit. (pp. 279-300).

Becker, U., \& Mesa-Lago, C. (2013). Re-Reformas de sistema de pensiones privatizadas en el mundo: estudio comparativo de Argentina, Bolivia, Chile y Hungría. In Revista de Trabajo del Centro de análisis del trabajo. México, DF: Plaza y Valdez.

Berry, C. (2016). Austerity, ageing and the financialisation of pension policy in the UK. British Politics, 11(1), 2-25.

Bertranou, F. (2006). Envejecimiento y Protección Social en América Latina. Santiago de Chile: Organización Internacional del Trabajo.

Bertranou, F., Calvo, E., \& Bertranou, E. (2009). ¿Está Latinoamérica alejándose de las cuentas individuales de pensiones? Center for Retirement Research at Boston College, Num. 9-14, 28-34.

Birgin, H., \& Pautassi, L. (2001). ¿Género en la reforma o reforma sin género? Desprotección social en las leyes provisionales en América Latina. Serie Mujer y desarrollo. CEPAL, LC/L.1558-P, 36.

Bonari, D., Curcio, J., \& Goldschmit, A. (2009). Cuenta de la Seguridad Social en la Argentina. In O. Centrangelo (Ed.), La seguridad social en América Latina y el Caribe. Una propuesta metodológica para su medición y aplicación a los casos de Argentina, Chile y Colombia. Santiago de Chile: CEPAL/PNUD.

Boyer, R. (2005). Changement d'epoque... mais diversité persistante es systèmes de protection sociale. In Vielle, P. Op cit. (pp. 33-62).

Campos Lima, M., \& Martín Artiles, A. (2014). Descontentamento na Europa en tempos da austertdade: da aço colectiva a paticipaçipaçao individual. Revista Critica de Ciencies Sociais, 103. https://doi.org/10.4000/rccs.5569. Retrieved from http://rccs.revues.org/5569

Campos Lima, M., \& Martín Artiles, A. (2018). Social Protest, descontent and polítics in Southern and Eastern Europe. Trasnsfer, 24, 1-21. https://doi.org/10.1177/1024258918762963.

Clasen, J., \& Clegg, D. (2012). Regulating the risks of unemployment: National adaptations to post-industrial labour markets in Europe. Oxford Scholarship Online.

Comisión Europea. (2003). Informe conjunto de la Comisión Europea y del Consejo sobre la adecuación y viabilidad de las pensiones, 6527/3/03. Brussels. Retrieved February 20, 2020, from https://eur-lex.europa.eu/legal-content/es/TXT/?uri=CELEX\%3A52002DC0737 
De la Fuente, A., Garcia, M. A., \& Sánchez, A. (2018). ¿Hacia una nueva reforma de las pensiones? Notas para el Pacto de Toledo. Madrid: FEDEA. Retrieved March 16, 2020, from https:// ocopen.org/biblioteca/pensiones/hacia-una-nueva-reforma-de-las-pensiones.pdf

Del Pino, E., \& Rubio Lara, J. (2016). Los estados del bienestar en la encrucijada. Madrid: Tecnos.

Del Valle, A. (2010). Comparando regímenes de bienestar en América Latina (pp. 61-76). Amsterdam: CEDLA, Centre for Latin American Research and Documentation. Retrieved from www.cedla.uva.nl. ISSN 0924-0608.

Department for Work and Pensions (DWP). (2010). Making automatic enrolment work. London: The Stationary Office.

DWP. (2013). The single tier pension: A simple foundation for saving. London: The Stationery Office.

European Commission. (2012). White paper: An agenda for adequate, safe and sustainable pensions. Brussels: European Commission. Retrieved February 20, 2020, from https://op.europa. eu/en/publication-detail/-/publication/32eda60f-d102-4292-bd01-ea7ac726b731/language-en

European Commission. (2020). Missoc: Comparative tables on social protection. Mutual System of Information on Social Protection. Retrieved February 20, 2020, from https://www.missoc. org/missoc-database/comparative-tables/

Expansión. (2020). Datos macro-economicos. Retrieved February 17, 2020, from https://datosmacro.expansion.com/deuda/uk

Foster, L. (2017). Active ageing, pensions and retirement in the UK. Journal of Population Ageing, $11(2), 117-132$.

Grady, J. (2016). Retirement and pension crisis. In S. Manfredi \& L. Vickers (Eds.), Challenges of active ageing for equality law and for the workplace (pp. 49-70). Basingstoke: Palgrave Macmillan.

Harris, B. (2004). The origins of the British Welfare State: Social welfare in England and Wales 1800-1945. Basingstoke: Palgrave Macmillan.

Harrison, B. (2011). Finding a role? The United Kingdom 1970-1990. Oxford: Oxford Universiy Press.

Hofäcker, D. (2015). In line or at odds with active ageing policies? Exploring patterns of retirement preferences in Europe. Ageing and Society, 35(7), 1529-1556.

Hopp, V., \& Lijterman, E. (2019). Work, social rights and protection in the Argentina of the neoliberal reconstruction. Revista Katálysis, 22(1), jan./abr. 2019, 66-79. Florianópolis, Santa Catarina, Brasil. ISSN 1982-0259. https://doi.org/10.1590/1982-02592019v22n1p66

ILO. (2019). Statistics. Retrieved December 3, 2019, from https://www.ilo.org/shinyapps/bulkexp lorer7/?lang=en\&segment=indicator\&id=SDG_B831_SEX_RT_A

Langley, P. (2008). The everyday live of global finance: Saving and borrowing in Anglo-America. Oxford: Oxford University Press.

Liedo, J. (2005). Los sistemas multipilar en la previsión social. Bolsa de Madrid, 143, 27-29. ISSN 0211-5336.

Lo Vuolo, R. M. (2008). Promesas falsas y necesidades inciertas. Acerca del proyecto de creación del Sistema Integrado de Previsión Argentino, Análisis de Coyuntura. Retrieved December 10, 2008, from http://www.ciepp.org.ar

Martín Artiles, A., \& Molina, O. (2015). ¿Participación financiera para sostener las pensiones? Entre la Democracia Industrial y la Motivación. Cuadernos de Relaciones Laborales, 33(2), 307-422.

Martín Artiles, A., Molina, O., \& Godino, A. (2016). Desocupació i política de "ingressos adequats" a Espanya i Itàlia. Anuario IET de Trabajo y Relaciones Laborales, 3, 94-112.

Mesa-Lago, C. (2000) Desarrollo social, reforma del Estado y de la seguridad social, al umbral del siglo XXI. Serie políticas sociales, 36. Santiago de Chile: CEPAL.

Mesa-Lago, C. (2004). Las reformas de pensiones en América Latina y su impacto en los principios de la seguridad social. Serie Financiamiento del Desarrollo, 144. Santiago de Chile: CEPAL.

Mesa-Lago, C. (2009). La ley de reforma de la previsión social argentina. Antecedentes, razones características y análisis de posibles resultados y riesgos. Revista Nueva Sociedad, 219, 14-31. 
Naczyk, M. (2018). Occupational welfare in the United Kingdom: From skill retention tool to social protection only for legitimate social risk. In D. Natali \& E. Pavolini (Eds.), Occupational welfare in Europe: Risks, opportunities and social partner involvement (pp. 79-102). Brussels: European Trade Union Institute.

OECD. (2019). OECD statistic. Retrieved March 16, 2020, from https://stats.oecd.org/Index. aspx ?DataSetCode=IDD

OECD. (2020). Pensions at glance 2019. Retrieved from https://www.oecd-ilibrary.org/sites/ b6d3dcfc-en/1/2/1/index.html?itemId=/content/publication/b6d3dcfc-en\&_csp_=a8e95975 da55b0299df9e90b37215621\&itemIGO=oecd\&itemContentType=book

Office for National Statistics (ONS). (2015). Wealth and assets survey 2015. London: ONS.

Palier, B. (2010). The long conservative corporatist road to welfare reforms. In B. Pallier (Ed.), Long goodbye to Bismarck? The politics of welfare reform in continental Europe (pp. 333-389). Amsterdam: Amsterdam University Press.

Panigo, D. T., \& Médici, F. (2013). El sistema de seguridad social en la Argentina: transformaciones recientes en perspectiva histórica. Perspectiva sobre el Estado, las políticas públicas y la gestión, 131, 1-24.

Pavolini, E., Ascoli, U., \& Mirabule, M. (2013). Tempi moderni, Il welfsare nella azienda in Italia. Bologna: Il Mulino.

Pierson, P. (1994). Dismantling the welfare state? Reagan, thatcher and the politics of retrenchment. New York: Cambridge University Press.

Rubio Lara, J. (2016). La Reforma de las pensiones de jubilación en perspectiva comparada. ¿Del Estado de Bienestar al Estado regulador? In E. del Pino \& M. J. Rubio Lara (Eds.), Los estados de bienestar en la encrucijada: políticas sociales en perspectiva comparada (pp. 268-292). Madrid: Tecnos. ISBN 978-84-309-6855-8.

Soto Pimentekl, V. (2015). La reforma de jubilación chileno en el año 2008. Reposotorio de FLACSO. Retrieved February 15, 2020, from https://repositorio.flacsoandes.edu.ec/handle/ $10469 / 8198$

Tangarife, C., Zelko, B., \& Durán, F. (2015). Análisis comparativo de los sistemas de seguridad social en Chile, Colombia y Uruguay a veinte años de las reformas neoliberales. Herramientas para el fortalecimiento de la agenda sindical, pp. 1-44.

Trampusch, C. (2007). Industrial relations as a source of solidarity in times of welfare state retrenchment. Journal of Social Poliucy, 35(2), 197-270.

Ubasart, G., \& Minteguiaga, A. (2017). Esping-Andersen en América Latina. Revista Política y Gobierno, 1, 213-236.

Uthoff, A. A. (2008). Sistema de Pensiones en Chile: reformando la reforma. Diálogo Político, 25(2), 59-71.

Vielle, P., Pochet, P., \& Cassier, I. (2005). L'État social actif. In Vers un changement de paradigm? Brussels: PIE-Peter Lang.

Watson, M. (2009). Investigating the potentially contradictory microfoundations of financialization. Economy and Society, 38(2), 255-277.

WorldBank.(1994).Avertingtheoldagecrisis: Policiestoprotecttheoldandpromote growth.Retrieved March 16, 2020, from http://documents.worldbank.org/curated/en/973571468174557899/ Averting-the-old-age-crisis-policies-to-protect-the-old-and-promote-growth

World Bank. (2004). Keeping the promise of old age income security in Latin America. Retrieved March 16, 2020, from http://documents.worldbank.org/curated/en/201171468773063370/ Keeping-the-promise-of-old-age-income-security-in-Latin-America

Yáñez, S. (2010). La dimensión de género en la reforma previsional chilena (Ley No 20.255 de reforma de pensiones). Santiago de Chile: CEPAL. ISSN print version 1564-170. ISSN Electronic version: 1680-8967. ISBN: 978-92-1-323403-7.

Zalakain, J., \& Barragué, B. (2017). Repensar las políticas sociales. Madrid: Grupo 5. 
Open Access This chapter is licensed under the terms of the Creative Commons Attribution 4.0 International License (http://creativecommons.org/licenses/by/4.0/), which permits use, sharing, adaptation, distribution and reproduction in any medium or format, as long as you give appropriate credit to the original author(s) and the source, provide a link to the Creative Commons licence and indicate if changes were made.

The images or other third party material in this chapter are included in the chapter's Creative Commons licence, unless indicated otherwise in a credit line to the material. If material is not included in the chapter's Creative Commons licence and your intended use is not permitted by statutory regulation or exceeds the permitted use, you will need to obtain permission directly from the copyright holder. 